\title{
Serum sclerostin is negatively associated with insulin sensitivity in obese but not lean women
}

\author{
Anouar Aznou' ${ }^{1}$, Rick Meijer ${ }^{1}$, Daniel van Raalte', Martin den Heijer ${ }^{1}$, Annemieke Heijboer ${ }^{2}$ and Renate de Jongh ${ }^{1}$ \\ ${ }^{1}$ Department of Internal Medicine, Amsterdam University Medical Centers, MB Amsterdam, the Netherlands \\ Endocrine Laboratory, Department of Clinical Chemistry, Amsterdam University Medical Centers, MB Amsterdam, the Netherlands \\ Correspondence should be addressed to R de Jongh: rt.dejongh@amsterdamumc.nI
}

\begin{abstract}
Objective: The mechanisms underlying the development of peripheral insulin resistance are complex. Several studies have linked sclerostin, an osteocyte-derived inhibitor of the Wnt/ $\beta$-catenin pathway, to obesity and insulin resistance. The aim of this study was to investigate (1) whether serum sclerostin is associated with insulin sensitivity in lean and/or obese women; and (2) whether hyperinsulinaemia affects serum sclerostin concentrations.

Design: A cross-sectional study.

Methods: Insulin sensitivity was measured in lean (BMI $\left.<25 \mathrm{~kg} / \mathrm{m}^{2}\right)$ and obese

$\left(\mathrm{BMI}>30 \mathrm{~kg} / \mathrm{m}^{2}\right)$ women using a hyperinsulinaemic-euglycaemic clamp. Serum sclerostin was measured at baseline and during the clamp procedure.

Results: We studied 21 lean and 22 obese women with a median age of 40 and 43 years and a median BMI of 22.4 and $33.5 \mathrm{~kg} / \mathrm{m}^{2}$, respectively. Obese women had higher serum sclerostin than lean women (122 \pm 33 vs $93 \pm 33 \mathrm{nmol} / \mathrm{L}, P<0.01)$. Higher serum sclerostin was associated with lower insulin sensitivity in obese, but not in lean individuals (difference in $M$-value between highest and lowest quartile: $-7.02 \mathrm{mg} / \mathrm{kg} / \mathrm{min}$, $P=0.03$ and $1.59 \mathrm{mg} / \mathrm{kg} / \mathrm{min}, P=0.50$, respectively). Hyperinsulinaemia did not affect serum sclerostin in lean nor obese women $(P>0.5)$.

Conclusion: Serum sclerostin is negatively associated with insulin sensitivity as measured with the hyperinsulinaemic-euglycaemic clamp in obese, but not lean women. This indicates a potential role of the Wnt/ $\beta$-catenin pathway in regulating insulin sensitivity particularly in obese individuals. Our findings remain hypothesis-generating and should be confirmed by additional studies.
\end{abstract}

Key Words
sclerostin
insulin
sensitivity
hyperinsulinemic-
euglycemic clamp
bone metabolism
obesity

\section{Introduction}

The exact mechanisms underlying the development of peripheral insulin resistance, a hallmark of type 2 diabetes mellitus (T2DM), are complex and not yet fully understood. Many metabolic and endocrine factors are involved in the process $(1,2)$. In recent years, bone has increasingly emerged as an endocrine organ and several hormones derived from bone tissue influence glucose and insulin metabolism (3).

One of the mechanisms through which bone tissue may affect glucose and insulin metabolism is through secretion of sclerostin. Sclerostin is an osteocyte-derived glycoprotein which functions as an inhibitor of the Wnt/ $\beta$-catenin signalling pathway (4). Without inhibitory control of this pathway, binding of Wnt proteins to their membrane-bound ligands elicit a cellular response which prevents the degradation of the intracellular protein $\beta$ catenin (5). The accumulation of $\beta$ catenin activates target genes in the cell nucleus. In bone tissue specifically, the Wnt/ $\beta$-catenin pathway helps to maintain physiological bone remodelling, that is, the balance between the

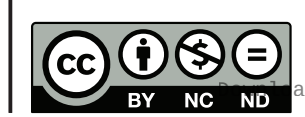

This work is licensed under a Creative Commons Attribution-NonCommercial-NoDerivatives 4.0 Anternationab bicense.ifica.com at 04/26/2023 10:37:19AM 
resorption and formation of bone by osteoclasts and osteoblasts, respectively (6). Activation of the pathway promotes bone formation, whereas inhibition favours resorption.

An interaction between the Wnt/ $\beta$-catenin signalling pathway and - more specifically - its inhibitor sclerostin and glucose and insulin metabolism is suggested in several recent studies, both in vitro and in vivo. In vitro stimulation of Wnt signalling enhances insulin sensitivity of rodent muscle cells through various mechanisms (7). In humans, correlations between serum sclerostin levels and serum parameters of insulin resistance in normal adults (8), prediabetic adults (9) and obese children and adolescents (10) have been described. These studies are, however, inconsistent in the presence and the direction of the association (11).

Adipose tissue appears to be involved in the association between Wnt signalling and insulin sensitivity. Serum sclerostin is positively correlated with fat mass $(12,13)$ and has been found to be higher in obese individuals in some (14), although not all (8), studies. Animal studies suggest that sclerostin is a causal factor in the development of obesity. In mice, overexpression of the Sost gene resulted in increased fat mass, whereas knockout of the Sost gene reduced adipose tissue mass and increased insulin sensitivity (15). In humans, expression of Wnt signalling genes in adipose tissue and insulin sensitivity are linked (2). We therefore hypothesised that the possible association between serum sclerostin and insulin sensitivity may be different for obese and nonobese individuals.

It may also be hypothesised that high circulating insulin concentrations affect Wnt signalling through an effect on the secretion of Wnt signalling inhibitors such as sclerostin. Hyperinsulinaemia significantly altered the expression of Wnt activators in human adipose and muscle cells (2). In humans, serum sclerostin is significantly higher in individuals with type 2 diabetes mellitus, who are also characterised by higher insulin concentrations, than in healthy individuals (16). The effect of induced acute hyperinsulinemia on the secretion of sclerostin into the circulation has, however, not been described previously.

Therefore, the aim of this study was to investigate the association between serum sclerostin and insulin sensitivity, as measured with a hyperinsulinaemiceuglycaemic clamp, in lean and obese women. The second aim is to investigate whether induced hyperinsulinaemia affects serum sclerostin levels.

\section{Materials and methods}

\section{Patients}

This study was carried out as a post hoc analysis of a crosssectional study (17). Premenopausal female participants were recruited. One reason for exclusively including women was to take into account the difference in body fat percentage and body fat distribution between men and women with similar body mass indices. Adipose tissue is proposed to play a distorting role in the association between bone and glucose metabolism. Altered Wnt signalling in specific types of adipose tissue may directly influence glucose metabolism in mice (18). Another reason is the smaller frequency in women of other factors than obesity known to be associated with impaired insulin sensitivity, such as smoking (19), hypertension and a history of cardiovascular diseases (20).

All participants were volunteers recruited through community-based strategies, that is, via flyers, posters and local newspapers. The size of the sample population was 43 individuals, with 21 lean volunteers and 22 obese volunteers. Inclusion criteria were age between 18 and 55 years old, BMI greater than $30 \mathrm{~kg} / \mathrm{m}^{2}$ and a waist circumference greater than $80 \mathrm{~cm}$ in the obese subgroup, BMI less than $25 \mathrm{~kg} / \mathrm{m}^{2}$ and a waist circumference less than $80 \mathrm{~cm}$ in the lean subgroup (17). Exclusion criteria included the presence of diabetes or impaired glucose tolerance (according to the ADA criteria (21)), medical history of hypertension or other cardiovascular disease (stroke, coronary artery disease, peripheral vascular disease, heart failure), use of medication for hypertension or diabetes, use of medication known to disturb endothelial function or glucose metabolism, family history of first-degree relative with diabetes, pregnancy and smoking. The original study protocol was approved by the medical ethics committee of the VU University Medical Center and conducted in accordance with the Declaration of Helsinki. Written consent has been obtained from each subject after full explanation of the purpose and nature of all procedures.

\section{Measurements}

\section{Baseline measurements}

During a screening visit to the clinic prior to the hyperinsulinaemic-euglycaemic clamp (HEC), anthropometric measurements and indices such as height, body weight, BMI, waist circumference and waist-to-hip ratio were obtained. Body fat percentage was measured using bioelectrical impedance analysis 
(Maltron BF-906, Rayleigh, UK). During this visit, a fasting blood sample was also obtained in which insulin serum levels were measured with standard laboratory methods used in routine care. Fasting glucose was measured using the YSI 2300 STAT Plus Analyzer (Yellow Springs, OH, USA).

\section{Sclerostin}

Serum sclerostin levels were measured in blood samples drawn after an overnight fast both at baseline and during hyperinsulinaemia as established during the last hour of the HEC procedure. Sclerostin was measured by the endocrine laboratory of Amsterdam UMC using an electrochemiluminescence assay (MSD 96-well MULTI-ARRAY Human Sclerostin Assay; Meso Scale Discovery), with an intra-assay $\mathrm{CV} \leq 6.0 \%$ and an interassay CV of $11 \%$. The lower limit of quantitation was $0.040 \mathrm{ng} / \mathrm{mL}$.

\section{Hyperinsulinemic-euglycemic clamp}

Two peripheral venous catheters were placed in each arm (antebrachial veins) of the participants. One catheter was used to infuse insulin (Actrapid, Novo Nordisk, Bagsvaerd, Denmark) at a primed $\left(240 \mathrm{mU} / \mathrm{m}^{2}\right)$, continuous rate of $40 \mathrm{mU} / \mathrm{m}^{2} / \mathrm{min}$ for $2 \mathrm{~h}$ in order to establish hyperinsulinaemia. A $20 \%$ glucose infusion was administered at a variable rate through the same catheter to maintain euglycaemia at whole-blood glucose levels of $5 \mathrm{mmol} / \mathrm{L}$ (YSI 2300 STAT Plus Analyzer, Yellow Springs, $\mathrm{OH}$, USA). Every $5 \mathrm{~min}$, venous blood samples were drawn from the other catheter to ensure euglycaemia was maintained and to adjust glucose infusion accordingly.

Insulin sensitivity was expressed as the $M$-value ( $\mathrm{mg} / \mathrm{kg}$ lean body weight/min) and was calculated as the average rate of glucose infusion needed to maintain euglycaemia during the last hour of the clamp. Glucose space correction and lean body weight correction were performed for the M-value as described previously (22).

\section{Statistical analysis}

Demographic and clinical characteristics for the total population and separately for the lean and obese subpopulations were reported. Based on the distribution of the variables, these characteristics were described as means with s.D. or medians with interquartile ranges.

Extreme outliers were excluded, which were defined as observations that deviate below the 25 th percentile or beyond the 75th percentile with a value equal to at least three times the interquartile range of the corresponding variable (23). Serum sclerostin values during hyperinsulinaemia demonstrated one extreme outlier with a value of $744 \mathrm{pmol} / \mathrm{L}$. The presence of this extreme value could not be explained on the basis of characteristics of the specific individual. This individual was excluded from the analysis of the effect of acute hyperinsulinaemia on serum sclerostin levels.

BMI was used to stratify the study population (lean: $\mathrm{BMI} \leq 25$ and obese: $\mathrm{BMI} \geq 30 \mathrm{~kg} / \mathrm{m}^{2}$ ). Potential interaction was investigated statistically by testing interaction terms. The $P$-value of its corresponding regression coefficient was used to determine the statistical significance of the possible interaction.

Differences between lean and obese women at baseline were evaluated by performing either a student's $t$-test or a Mann-Whitney U-test in case of normally distributed and non-normally distributed variables, respectively.

To analyse the association between serum sclerostin levels and the corrected $M$ value, linear regression analysis was performed. Linearity was investigated by categorising the serum sclerostin variable into quartiles and creating three corresponding dummy variables. Regression coefficients, corresponding $P$-values and 95\% CI were reported for both the crude and adjusted models. In case of non-linearity, quartiles of the independent variable were analysed instead.

Potential confounding was investigated by performing univariate analysis. Confounding variables that caused a change of $10 \%$ or more in the regression coefficient in the relationship between serum sclerostin and the corrected $M$ value were then included in a multivariate analysis. Sclerostin appears to be associated with BMI, body fat and age (24). Since these variables are widely known to associated with insulin resistance, age and various measures of body weight and fat tissue were considered as biologically plausible confounding variables in this study.

Finally, the effect of hyperinsulinaemia on serum sclerostin was analysed using a paired student's $t$-test. The assumption of normal distribution of the outcome variable was assessed graphically by studying whether the corresponding histogram followed the normal distribution curve.

All $P$-values smaller than 0.05 were considered statistically significant. The data were analysed using SPSS version 26.0 (SPSS, Inc.). (c) 2021 The authors Published by Bioscientifica Ltd
This work is licensed under a Creative Commons Attribution-NonCommercial-NoDerivatives 4.0 elnternationab ficense.ifica com at 04/26/2023 10:37:19AM 


\section{Results}

\section{Baseline characteristics}

The baseline characteristics are depicted in Table 1.

\section{Associations between serum sclerostin and insulin sensitivity}

There was significant interaction of BMI category (lean: BMI $\leq 25 \mathrm{~kg} / \mathrm{m}^{2}$ and obese: BMI $\geq 30 \mathrm{~kg} / \mathrm{m}^{2}$ ) in the association of serum sclerostin and the corrected $M$-value $(P=0.009)$. We will present all the results stratified for BMI category.

In the obese but not the lean individuals, serum sclerostin fulfilled criteria for linearity. Therefore, we first performed the analyses for sclerostin quartiles in the lean group and the obese group. This demonstrated a negative association between serum sclerostin and insulin sensitivity in the obese group $(P=0.026)$. The mean $M$-value of the highest quartile of serum sclerostin concentrations was $7.0 \mathrm{mg} / \mathrm{kg} / \mathrm{min}$ lower than the $M$-value of the lowest quartile (Fig. 1A). There was no association in the lean group $(P=0.58$; Fig. 1B). In the obese group, an additional linear regression analysis with serum sclerostin on a continuous scale was performed. This revealed a significant negative linear association between serum sclerostin and insulin sensitivity in the obese individuals. For each difference of $10 \mathrm{pmol} / \mathrm{L}$ in serum sclerostin, the corrected $M$-value changed $0.9 \mathrm{mg} / \mathrm{kg}$ lean body weight/ min (Fig. 2 and Table 2). The association weakened, yet remained statistically significant after adjustment for age, BMI, body fat percentage, fat mass, waist circumference and waist-to-hip ratio (Table 2).

\section{Effects of acute hyperinsulinaemia on serum sclerostin}

There was no effect of induced acute hyperinsulinaemia on serum sclerostin levels in either the obese (from $122 \pm 33$ to $125 \pm 43 \mathrm{pmol} / \mathrm{L}, P=0.54$ ) or lean individuals (from $93 \pm 34$ to $90 \pm 39 \mathrm{pmol} / \mathrm{L}, P=0.74$ ).

\section{Discussion}

The main finding of this study is that in obese but not lean individuals, higher serum sclerostin concentrations are associated with lower peripheral insulin sensitivity as measured with the state-of-the-art hyperinsulinaemiceuglycaemic clamp. Acute hyperinsulinaemia did not have an effect on serum sclerostin concentrations.

In our study, serum sclerostin level at baseline was significantly higher in the obese subgroup as compared to the lean subgroup. This finding is in line with most (11, $12,13,24)$, although not all (14), previous studies that investigated the relationship between serum sclerostin and obesity and body fat measures. Several hypotheses can be postulated as an explanation for this finding. Lower physical activity may offer an explanation, since an independent positive association between serum sclerostin and physical activity has been described (24). This correlation may be due to the inhibitory effect of mechanical force on sclerostin expression in bone tissue (25). A decrease in physical activity could thus cause an increase in local sclerostin production and an increase in systemic sclerostin levels. Another explanation would be that the chronic inflammation associated with obesity increases sclerostin secretion by bone tissue. Indeed, in mice,

Table 1 Baseline characteristics.

\begin{tabular}{l}
\hline$n$ \\
Age (years) \\
Weight (kg) \\
BMI \\
Body fat (\%) \\
Waist circumference (cm) \\
Body fat mass (kg) \\
Waist-to-hip ratio \\
Fasting glucose (mmol/L) \\
Fasting insulin (pmol/L) \\
Glucose concentration during the clamp (mmol/L) \\
Insulin concentration during the clamp (pmol/L) \\
Serum sclerostin level (pmol/L) \\
M-value (mg/kg/min)
\end{tabular}

\begin{tabular}{c}
\hline Obese individuals \\
\hline 22 \\
$43(27-50)$ \\
$100.9( \pm 16.5)$ \\
$33.5(31.9-34.5)$ \\
$43.8( \pm 5.1)$ \\
$106.0(100.8-115.2)$ \\
$43.6(35.8-51.8)$ \\
$0.89( \pm 0.06)$ \\
$4.6( \pm 0.8)$ \\
$66.8(45.1-95.1)$ \\
$4.9( \pm 0.3)$ \\
$647( \pm 97)$ \\
$122( \pm 33)$ \\
$13.2( \pm 5.1)$
\end{tabular}

\begin{tabular}{c}
\hline Lean individuals \\
\hline 21 \\
$40(25-47)$ \\
$65( \pm 6.8)$ \\
$22.4(20.2-23.9)$ \\
$25.2( \pm 5.5)$ \\
$76.0(72.5-84.0)$ \\
$14.5(12.5-21.4)$ \\
$0.82( \pm 0.06)$ \\
$4.3( \pm 0.3)$ \\
$29.8(26.6-44.7)$ \\
$5.0( \pm 0.3)$ \\
$551( \pm 103)$ \\
$93( \pm 33)$ \\
$16.3( \pm 4.1)$
\end{tabular}

\begin{tabular}{rr}
\hline P-value \\
\hline \\
\\
0.38 \\
$<0.01$ \\
$<0.01$ \\
$<0.01$ \\
$<0.01$ \\
$<0.01$ \\
$<0.01$ \\
0.15 \\
$<0.01$ \\
0.29 \\
$<0.01$ \\
$<0.01$ \\
0.03
\end{tabular}

Mean values ( \pm S.D.) or median values (interquartile range) are presented based on the distribution of the variables.

https://ec.bioscientifica.com https://doi.org/10.1530/EC-20-0535 (c) 2021 The authors Published by Bioscientifica Ltd

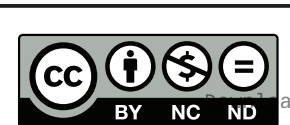

This work is licensed under a Creative Commons Attribution-NonCommercial-NoDerivatives 4.0 elnternationad dicense.ifica . com at $04 / 26 / 2023$ 10:37:19AM 
A

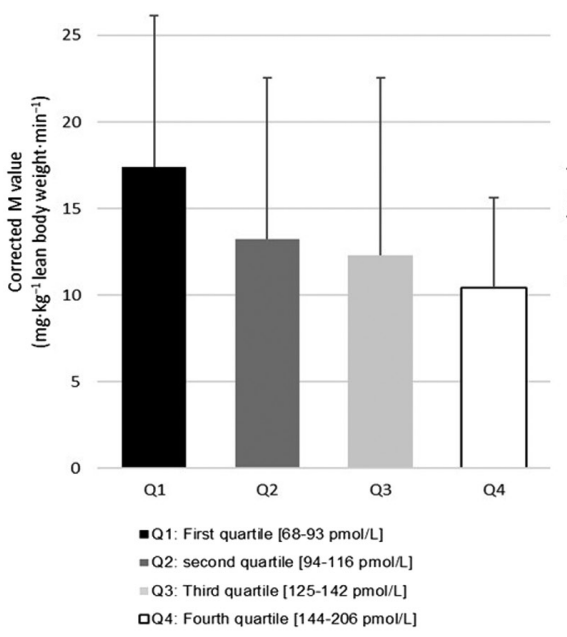

B

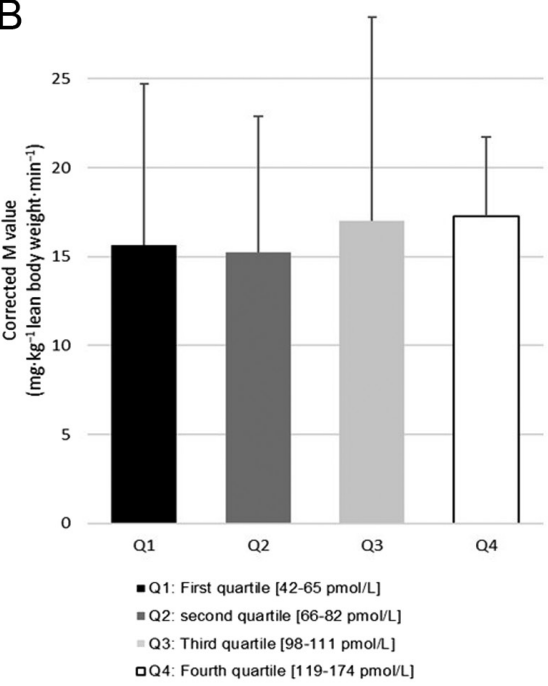

The whiskers represent the value of the standard deviation of the corresponding mean $\mathrm{M}$ value.

Figure 1

Corrected mean $M$-Value presented for serum sclerostin quartiles in obese (panel A) and lean women (panel B). the pro-inflammatory cytokine tumour necrosis factor (TNF)- $\alpha$ has been shown to increase sclerostin gene expression $(26,27)$.

In the obese group, the negative association between serum sclerostin and insulin sensitivity was independent of age and various weight and body fat indices. The difference in this relationship between obese and lean individuals is intriguing. The presence of a negative association between serum sclerostin and peripheral insulin sensitivity in obese individuals is in accordance with the study by Daniele et al. (9). However, they did not specifically include a lean subgroup. This is of particular interest because the effect of sclerostin on Wnt signalling in adipose tissue may play an important role in the development of peripheral insulin resistance. Overexpression of sclerostin in mice has been demonstrated to not only induce lower insulin sensitivity, but also hypertrophy of adipocytes and an overall increase in body fat mass (15). In south Asian men, both increased serum sclerostin levels and decreased expression of insulin signalling genes in white adipose tissue were found (28). Also, serum sclerostin has been shown to be negatively related to estimates of insulin sensitivity of different cell types, such as muscle and liver cells, but also to insulin sensitivity of adipocytes (9). These studies show a potential interfering effect of adipose tissue on a potential effect of sclerostin on insulin sensitivity. Also, stimulation of the Wnt pathway directly influences cellular insulin signalling. In rodents, stimulation of Wnt pathway in target cells of insulin has shown to increase gene expression of multiple mediators of the insulin signalling pathway $(29,30)$. Accordingly, Wnt signalling stimulates glucose uptake in these cells (7).

Contrary to our findings, a recent study in children (10) showed a positive association between serum sclerostin

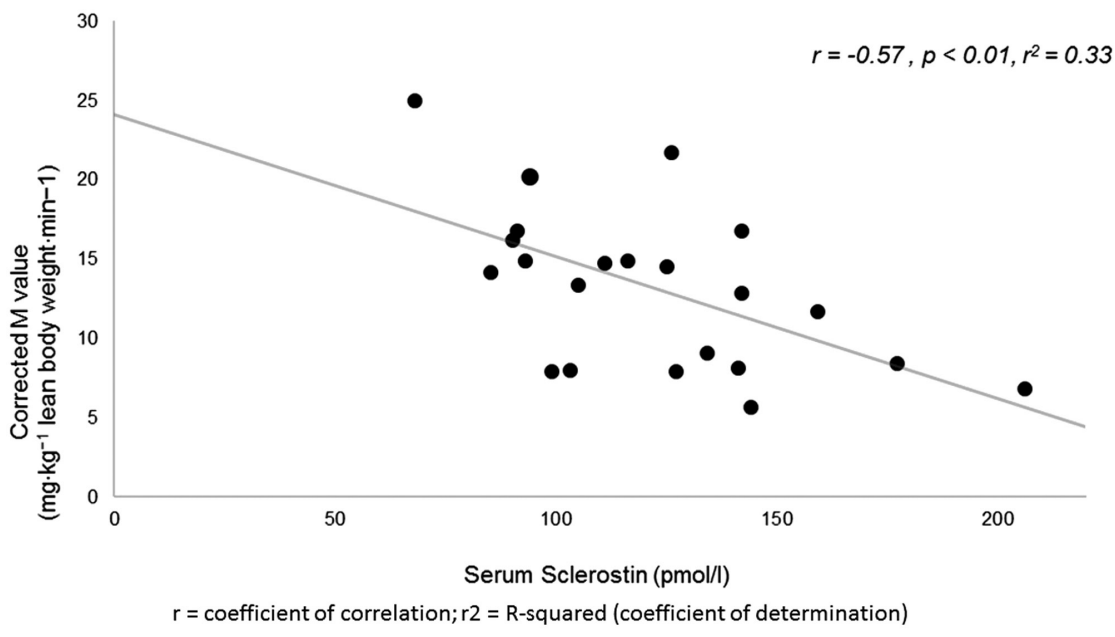

Figure 2

Univariate regression analysis of serum sclerostin with corrected $M$-value in obese women. https://ec.bioscientifica.com https://doi.org/10.1530/EC-20-0535 (c) 2021 The authors Published by Bioscientifica Ltd
This work is licensed under a Creative Commons Attribution-NonCommercial-NoDerivatives 4.0 delfternationab ficense ifica.com at 04/26/2023 10:37:19AM 
Table 2 Linear regression analysis of the relation between serum sclerostin and the corrected $M$-value in obese individuals.

\begin{tabular}{|c|c|c|c|}
\hline & $\begin{array}{l}\text { Regression } \\
\text { coefficient }\end{array}$ & $95 \% \mathrm{Cl}$ & $P$-value \\
\hline Unadjusted model & -0.090 & $-0.15 ;-0.030$ & 0.005 \\
\hline $\begin{array}{l}\text { Adjusted for BMI, } \\
\text { fat } \% \text { and WC }\end{array}$ & -0.078 & $-0.14 ;-0.017$ & 0.016 \\
\hline Adjusted for BMI & -0.072 & $-0.13 ;-0.011$ & 0.024 \\
\hline Adjusted for fat \% & -0.079 & $-0.13 ;-0.025$ & 0.006 \\
\hline Adjusted for WC & -0.079 & $-0.14 ;-0.018$ & 0.013 \\
\hline
\end{tabular}

Fat\%, body fat percentage; WC, waist circumference.

and insulin sensitivity. Apart from the obvious difference in age of the study population, this contradictory finding might be related to the different measure used for insulin sensitivity, known as the homeostasis model assessment (HOMA). HOMA is mostly a measure of hepatic insulin sensitivity, whereas the hyperinsulinaemic-euglycaemic clamp primarily measures muscle insulin sensitivity. However, another recent study that used HOMA in adults did find a negative association between serum sclerostin and insulin sensitivity (8).

The effect of hyperinsulinaemia on sclerostin levels was another focus of this study, since hyperinsulinaemia has been shown to alter the expression of Wnt signalling genes in human adipose and muscle tissue (2) and activators of the Wnt pathway stimulate insulin secretion in vitro (31). We therefore hypothesised that induction of hyperinsulinaemia may have a negative feedback on Wnt signalling by promoting the expression of its inhibitors, such as sclerostin. However, serum sclerostin did not increase in the obese or lean group during the clamp. Overall, induced acute hyperinsulinaemia has no effect on serum sclerostin concentrations. Whether prolonged hyperinsulinaemia increases serum sclerostin concentrations remains to be studied.

\section{Strengths and limitations}

The main strength of this study was the use of the hyperinsulinaemic-euglycaemic clamp technique, which is considered to be the gold standard for measuring peripheral insulin sensitivity. The hyperinsulinemia induced during the clamp procedure also enabled us to obtain serum sclerostin concentrations under hyperinsulinaemic conditions. Due to the relatively good health of the participants, the influence of disease-related confounding factors (such as side-effects of medication) on the validity of the results was negligible.

This study has several important limitations. First, only female participants were included. Findings cannot be extrapolated to men particularly because of gender specificity of body fat amount and distribution. Secondly, the obese individuals in this study had a relatively high peripheral insulin sensitivity and thus findings may not be extrapolated to other obese populations. Thirdly, the small size of the study population induces a large amount of variation due to chance and thus the risk that significant findings are missed. In our study, however, the association between serum sclerostin and peripheral insulin sensitivity in lean individuals was absent and the effect size of insulin infusion on serum sclerostin was close to zero. An increase in sample size is thus highly unlikely to have resulted in different conclusions. Another weakness of this study was its cross-sectional design. Lastly, only the role of sclerostin was studied, because we were not able to determine concentrations of other inhibitors of the Wnt/ $\beta$-catenin, such as Dickkopf- 1 . We were also not able to measure serum markers of bone turnover, such as procollageen type I N propeptide (P1NP) or C-terminal telopeptide of type 1 collagen (CTX). Due to these limitations and the fairly strict inclusion criteria, the generalisability of these results is compromised and caution should be taken when translating the results of this study to other populations.

\section{Future research and clinical relevance}

This study should be regarded as a hypothesis-generating study, which proposes bone tissue to be associated with reduced insulin sensitivity through secretion of the bone hormone sclerostin in humans, with a possible mediating role for adipose tissue. This finding may suggest a possible new therapeutic perspective on treating insulin resistance in obese individuals, by interfering with the Wnt signalling pathway. As of recently, the use of antisclerostin antibodies in the treatment of osteoporosis in postmenopausal women has been officially approved by the United States FDA, and the European Medical Agency.

However, more research is needed to prove a causal relationship between higher serum sclerostin and reduced peripheral insulin sensitivity. Further research should therefore focus on exploring this relationship in larger study populations also with other measurements of Wnt signalling activity and a wide variety of body composition. Even more important are the studies after the effect of treatment with sclerostin antibodies in humans on glucose and insulin metabolism.

No in vivo evidence was found to support the other hypothesis of this study, that is, the positive feedback of

This work is licensed under a Creative Commons Attribution-NonCommercial-NoDerivatives 4.0 International License.ifica, com at $04 / 26 / 2023$ 10:37:19 AM 
hyperinsulinaemia on sclerostin secretion in humans. To more fundamentally investigate this hypothesis, it would be interesting to study the effect of exposure to insulin on the expression of sclerostin genes in human osteocytes.

\section{Conclusion}

The results of this study show a negative correlation between serum sclerostin and peripheral insulin sensitivity in obese women but not in lean women and no effect of hyperinsulinaemia on serum sclerostin levels. These findings support the growing evidence of the role of bone tissue in the development of altered insulin sensitivity and the complex interaction with adipose tissue therein.

\section{Declaration of interest}

The authors declare that there is no conflict of interest that could be perceived as prejudicing the impartiality of the research reported.

\section{Funding}

This research did not receive any specific grant from any funding agency in the public, commercial or not-for-profit sector.

\section{Acknowledgement}

The authors would like to express their since gratitude to the participants of this study.

\section{References}

1 Samuel VT \& Shulman GI. Mechanisms for insulin resistance: common threads and missing links. Cell 2012148 852-871. (https:// doi.org/10.1016/j.cell.2012.02.017)

2 Karczewska-Kupczewska M, Stefanowicz M, Matulewicz N, Nikołajuk A \& Strączkowski M. Wnt signaling genes in adipose tissue and skeletal muscle of humans with different degrees of insulin sensitivity. Journal of Clinical Endocrinology and Metabolism 2016101 3079-3087. (https://doi.org/10.1210/jc.2016-1594)

3 Conte C, Epstein S \& Napoli N. Insulin resistance and bone: a biological partnership. Acta Diabetologica 201855 305-314. (https:// doi.org/10.1007/s00592-018-1101-7)

4 Semënov M, Tamai K \& He X. SOST is a ligand for LRP5/LRP6 and a Wnt signaling inhibitor. Journal of Biological Chemistry 2005280 26770-26775. (https://doi.org/10.1074/jbc.M504308200)

5 Duan P \& Bonewald LF. The role of the wnt/ $\beta$-catenin signaling pathway in formation and maintenance of bone and teeth. International Journal of Biochemistry and Cell Biology 201677 23-29. (https://doi.org/10.1016/j.biocel.2016.05.015)

6 Kramer I, Halleux C, Keller H, Pegurri M, Gooi JH, Weber PB, Feng JQ, Bonewald LF \& Kneissel M. Osteocyte Wnt/beta-catenin signaling is required for normal bone homeostasis. Molecular and Cellular Biology 201030 3071-3085. (https://doi.org/10.1128/MCB.01428-09)

7 Abiola M, Favier M, Christodoulou-Vafeiadou E, Pichard AL, Martelly I \& Guillet-Deniau I. Activation of Wnt/beta-catenin signaling increases insulin sensitivity through a reciprocal regulation of Wnt10b and SREBP-1c in skeletal muscle cells. PLoS ONE 20094 e8509. (https://doi.org/10.1371/journal.pone.0008509)

8 Azzam EZ, Ata MN, Younan DN, Salem TM \& Abdul-Aziz AA. DObesity: relationship between vitamin $\mathrm{D}$ deficiency, obesity and sclerostin as a novel biomarker of bone metabolism. Journal of Clinical and Translational Endocrinology 201917 100197. (https://doi. org/10.1016/j.jcte.2019.100197)

9 Daniele G, Winnier D, Mari A, Bruder J, Fourcaudot M, Pengou Z, Tripathy D, Jenkinson C \& Folli F. Sclerostin and insulin resistance in prediabetes: evidence of a cross talk between bone and glucose metabolism. Diabetes Care 201538 1509-1517. (https://doi. org/10.2337/dc14-2989)

10 Wędrychowicz A, Sztefko K \& Starzyk JB. Sclerostin and its association with insulin resistance in children and adolescents. Bone 2019120 232-238. (https://doi.org/10.1016/j.bone.2018.07.021)

11 Stanik J, Kratzsch J, Landgraf K, Vogel M, Thiery J, Kiess W \& Körner A. The bone markers sclerostin, osteoprotegerin, and bonespecific alkaline phosphatase are related to insulin resistance in children and adolescents, independent of their association with growth and obesity. Hormone Research in Paediatrics 201991 1-8. (https://doi.org/10.1159/000497113)

12 Urano T, Shiraki M, Ouchi Y \& Inoue S. Association of circulating sclerostin levels with fat mass and metabolic disease-related markers in Japanese postmenopausal women. Journal of Clinical Endocrinology and Metabolism 201297 E1473-E1477. (https://doi.org/10.1210/ jc.2012-1218)

13 Sheng Z, Tong D, Ou Y, Zhang H, Zhang Z, Li S, Zhou J, Zhang J $\&$ Liao E. Serum sclerostin levels were positively correlated with fat mass and bone mineral density in central south Chinese postmenopausal women. Clinical Endocrinology 201276 797-801. (https://doi.org/10.1111/j.1365-2265.2011.04315.x)

14 Ardawi MS, Al-Kadi HA, Rouzi AA \& Qari MH. Determinants of serum sclerostin in healthy pre- and postmenopausal women. Journal of Bone and Mineral Research 201126 2812-2822. (https://doi. org/10.1002/jbmr.479)

15 Kim SP, Frey JL, Li Z, Kushwaha P, Zoch ML, Tomlinson RE, Da H, Aja S, Noh HL, Kim JK, et al. Sclerostin influences body composition by regulating catabolic and anabolic metabolism in adipocytes. PNAS 2017114 E11238-E11247. (https://doi.org/10.1073/ pnas.1707876115)

16 García-Martín A, Rozas-Moreno P, Reyes-García R, MoralesSantana S, García-Fontana B, García-Salcedo JA \& MuñozTorres M. Circulating levels of sclerostin are increased in patients with type 2 diabetes mellitus. Journal of Clinical Endocrinology and Metabolism 201297 234-241. (https://doi.org/10.1210/jc.20112186)

17 Meijer RI, Serné EH, Korkmaz HI, van der Peet DL, de Boer MP, Niessen HW, van Hinsbergh VW, Yudkin JS, Smulders YM \& Eringa EC. Insulin-induced changes in skeletal muscle microvascular perfusion are dependent upon perivascular adipose tissue in women. Diabetologia 201558 1907-1915. (https://doi.org/10.1007/s00125015-3606-8)

18 Zeve D, Seo J, Suh JM, Stenesen D, Tang W, Berglund ED, Wan Y, Williams LJ, Lim A, Martinez MJ, et al. Wnt signaling activation in adipose progenitors promotes insulin-independent muscle glucose uptake. Cell Metabolism 201215 492-504. (https://doi.org/10.1016/j. cmet.2012.03.010)

19 Maddatu J, Anderson-Baucum E \& Evans-Molina C. Smoking and the risk of type 2 diabetes. Translational Research 2017184 101-107. (https://doi.org/10.1016/j.trsl.2017.02.004)

20 Petrie JR, Guzik TJ \& Touyz RM. Diabetes, hypertension, and cardiovascular disease: clinical insights and vascular mechanisms. Canadian Journal of Cardiology 201834 575-584. (https://doi. org/10.1016/j.cjca.2017.12.005)

21 American Diabetes Association. 2. Classification and diagnosis of diabetes: standards of medical care in diabetes-2019. 
Diabetes Care 201942 (Supplement 1) S13-S28. (https://doi. org/10.2337/dc19-S002)

22 DeFronzo RA, Tobin JD \& Andres R. Glucose clamp technique: a method for quantifying insulin secretion and resistance. American Journal of Physiology 1979237 E214-E223. (https://doi.org/10.1152/ ajpendo.1979.237.3.E214)

23 Hoaglin DC. John W. Tukey and data analysis. Statistical Science 2003 18 311-318. (https://doi.org/10.1214/ss/1076102418)

24 Amrein K, Amrein S, Drexler C, Dimai HP, Dobnig H, Pfeifer K, Tomaschitz A, Pieber TR \& Fahrleitner-Pammer A. Sclerostin and its association with physical activity, age, gender, body composition, and bone mineral content in healthy adults. Journal of Clinical Endocrinology and Metabolism 201297 148-154. (https://doi. org/10.1210/jc.2011-2152)

25 Delgado-Calle J, Sato AY \& Bellido T. Role and mechanism of action of sclerostin in bone. Bone 201796 29-37. (https://doi.org/10.1016/j. bone.2016.10.007)

26 Baek K, Hwang HR, Park HJ, Kwon A, Qadir AS, Ko SH, Woo KM, Ryoo HM, Kim GS \& Baek JH. TNF- $\alpha$ upregulates sclerostin expression in obese mice fed a high-fat diet. Journal of Cellular Physiology 2014229 640-650. (https://doi.org/10.1002/jcp.24487)

27 Heiland GR, Zwerina K, Baum W, Kireva T, Distler JH, Grisanti M, Asuncion F, Li X, Ominsky M, Richards W, et al. Neutralisation of Dkk-1 protects from systemic bone loss during inflammation and reduces sclerostin expression. Annals of the Rheumatic Diseases 201069 2152-2159. (https://doi.org/10.1136/ard.2010.132852)

28 Janssen LGM, Van Dam AD, Hanssen MJW, Kooijman S, Nahon KJ, Reinders H, Jazet IM, Van Marken Lichtenbelt WD, Rensen PCN, Appelman-Dijkstra NM, et al. Higher plasma sclerostin and lower Wnt signaling gene expression in white adipose tissue of prediabetic South Asian men compared with white Caucasian men. Diabetes and Metabolism Journal 202044 326-335. (https://doi.org/10.4093/ dmj.2019.0031)

29 Palsgaard J, Emanuelli B, Winnay JN, Sumara G, Karsenty G \& Kahn CR. Cross-talk between insulin and Wnt signaling in preadipocytes: role of Wnt co-receptor low density lipoprotein receptor-related protein-5 (LRP5). Journal of Biological Chemistry 2012287 12016-12026. (https://doi.org/10.1074/jbc.

M111.337048)

30 Yoon JC, Ng A, Kim BH, Bianco A, Xavier RJ \& Elledge SJ. Wnt signaling regulates mitochondrial physiology and insulin sensitivity. Genes and Development 201024 1507-1518. (https://doi.org/10.1101/ gad.1924910)

31 Schinner S, Ulgen F, Papewalis C, Schott M, Woelk A, Vidal-Puig A \& Scherbaum WA. Regulation of insulin secretion, glucokinase gene transcription and beta cell proliferation by adipocyte-derived Wnt signalling molecules. Diabetologia 200851 147-154. (https://doi. org/10.1007/s00125-007-0848-0)

Received in final form 5 January 2021

Accepted 20 January 2021

Accepted Manuscript published online 23 January 2021 https://ec.bioscientifica.com https://doi.org/10.1530/EC-20-0535 (c) 2021 The authors Published by Bioscientifica Ltd
This work is licensed under a Creative Commons Attribution-NonCommercial-NoDerivatives 4.0 Internationad dicense ifica. com at 04/26/2023 10:37:19AM 